\title{
A potential fast growing tree for Agroforestry and Carbon Sequestration in India: Anthocephalus cadamba (Roxb.) Miq.
}

\author{
Arvind Bijalwan $^{1,}$, , Manmohan J. R. Dobriyal ${ }^{2}$, Bhartiya J. K. ${ }^{3}$ \\ ${ }^{1}$ Indian Institute of Forest management (IIFM), Nehru Nagar, Bhopal-462 003, M.P., India \\ ${ }^{2}$ Department of Silviculture and Agroforestry, ASPEE College of Horticulture and Forestry, Navsari Agricultural University, Navsari - 396 \\ 450, Gujarat, India \\ ${ }^{3}$ Saranda Forest Division, Chaiwasa, Jharkhand, India
}

Email address:

arvindbijalwan276@gmail.com (A. Bijalwan)

\section{To cite this article:}

Arvind Bijalwan, Manmohan J. R. Dobriyal, Bhartiya J. K.. A Potential Fast Growing Tree for Agroforestry and Carbon Sequestration in India: Anthocephalus cadamba (Roxb.) Miq.. American Journal of Agriculture and Forestry. Vol. 2, No. 6, 2014, pp. $296-301$. doi: 10.11648/j.ajaf.20140206.21

\begin{abstract}
Anthocephalus cadamba commonly known as Kadamb tree In India is a large tropical tree with straight cylindrical bole belongs to family Rubiaceae. A. cadamba tree is fast growing in nature and can grow in different parts of India. Considering the high demand of wood in India; A. cadamba is one of the promising and potential trees, being grown on the farm land in the form of Agroforestry. The wood of $A$. cadamba is multipurpose in nature having white to creamy white and straight grain with fine to medium texture wood which is used in variety of services such as ply-wood, pencil making, match splints, pulp wood for paper, packing cases, toys, wooden shoes, flooring, carving and crates etc. The fast decomposition rate of $A$. cadamba is also make it more compatible for the emerging agroforestry systems in various parts of India and considered to be very useful tree in agroforestry and Carbon Sequestration.
\end{abstract}

Keywords: Anthocephalus Cadamba, Agroforestry, Productivity, Fast Growing, Plantation, Carbon Sequestration, Intercropping

\section{Introduction}

To meet rising population demand for food and wood in India there is intense pressure on cultivable land and existing forests. The escalating demand of food can be attained either by increasing the farm area or the productivity, however, to increase the farm area has limited options therefore, enhancing the productivity of agricultural field with integration of trees, as agroforestry is the only economic and viable option. In the order to meet the requirement, particularly for wood and tree derived produce the fast growing species are playing major role to increase the productivity. On the other hand the increasing concentration of Carbon in the atmosphere is creating difficulty to the biological entities which needs to be minimized, where fast growing tree are playing role in Carbon Sequestration.

At present the thrust has been given to the exotic species in India like Eucalyptus, Populur, Casurina, Robinia, Mangium etc in Haryana, Punjab, Western Uttar Pradesh and parts of
Uttarakhand along with some other states plantation under agroforestry are mainly comprised Eucalyptus and Poplar. Moreover the tree species like Acacia, Casurina, and Teak etc are being encouraged in agroforestry but still adoption is average only. These trees has limitation for the most of the agro-climatic regions of India particularly Madhya Pradesh, Assam, West Bengal, North Eastern states and Maharashtra. However, the tree namely Anthocephalus cadamba can grow well in these states, therefore, A. cadamba tree can be taken into the agroforestry and farm forestry model of most of the states of India to minimize the gap between demand and supply for wood and wood based industries.

In India the Kadamb tree (A. cadamba) is highly regarded as a sacred tree to the Lord Krishna and included in the Indian religions and cultures. The Lord Krishna and Radha encompassed their love play in the generous and endearing scented shade of Kadamb tree. Kadamb scientifically know as Anthocephalus cadamba (Roxb.) Miq. Syn. Neolamarckia cadamba var A. chinensis is a large tropical tree with broad 
crown and straight cylindrical bole having average height about 15 meters belongs to family rubiaceae. In the favourable climatic condition this tree attains a height of 20 meters or more with a clean bole of about 9 meter and a diameter of 40 to $60 \mathrm{~cm}$ (Figure $1 \& 2$ ). The bark is generally smooth in the initial stage which turns to darker in the older stage with exfoliating nature. The tree is aesthetic and deciduous in nature but sometimes evergreen and semievergreen (semi-deciduous) in nature. The flowers of the tree are small and orange colour in dense terminal globose heads, 2.5 to $5 \mathrm{~cm}$ in diameter however the fruit is a pseudocarp, is a globose, orange fleshy mass of closely packed capsules with each bears a numerous minute angular seeds [1]. The tree is near to leafless during in the hot season. The flowers are bisexual, small in size, orange in colour, highly scented in globose heads appear mainly May to July however the fruits ripen August to October and fall in January to February. The tree starts flowering and fruiting an early age even at an age of 6 to 7 years (Figure $3 \& 4$ ).

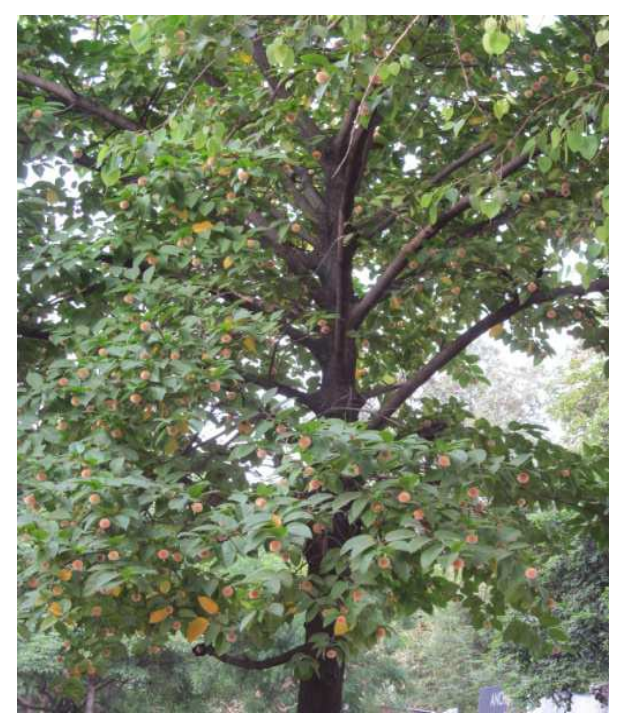

Fig. 1. Anthocephalus cadamba Tree

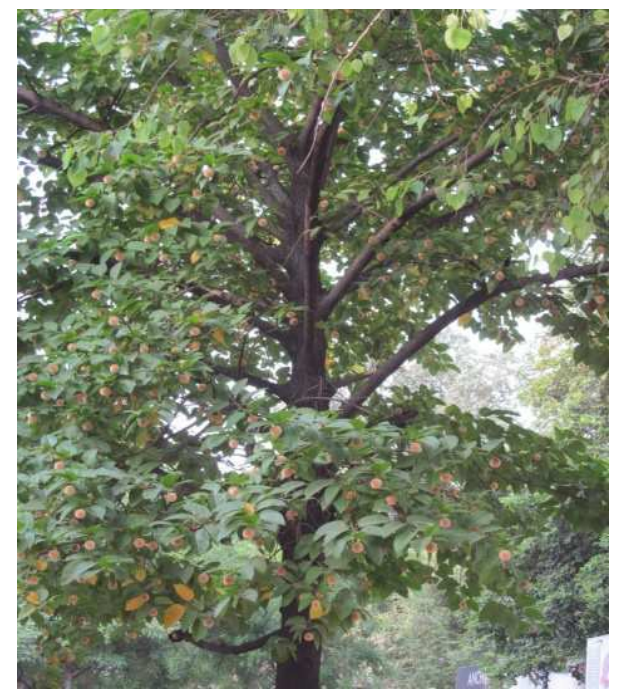

Fig. 2. Anthocephalus cadamba Tree

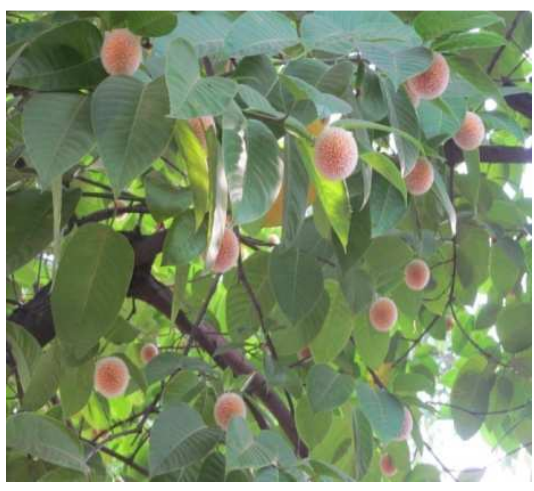

Fig. 3. Leaves and Flowers of A. cadamba

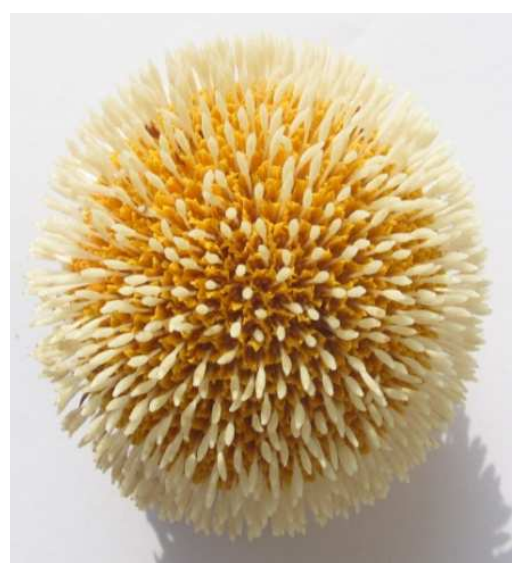

Fig. 4. Flower of A. cadamba

\section{Distribution and Uses}

This tree is native to South and Southeast Asia, including India, Indo-Malayan region, Jawa, Sumatra, China, Indonesia, Malaysia, Bangladesh, Sri Lanka, Combodia Papua New Guinea, Philippines and Singapore. In India it occurs in the Sub-Himalayan tract from Nepal eastward to West Bengal and Assam. In other part of India it found in Bihar, Chattisgarh, Madhya Pradesh, Andhra Pradesh and evergreen forest of Karnataka to Kerala [2], the species is also observed in Haldwani Division of Uttarakhand rarely growing on moist and swampy land [3]. It is an ingredient of southern tropical semi evergreen forests, secondary north Indian tropical moist deciduous forest and tropical fresh water swamp forest [4]. Due to the fast growing nature and complementary to annuals in variety of soils it is most suitable species to integrate and mass planting in agroforestry. In India this tree species is being used in plantation, particularly in agroforestry and farm-forestry practices. This species is considered to be increasingly important for wood based industries. In Arunachal Pradesh it is well adopted in agro-forestry.

The wood of A. cadamba is white to creamy white, odourless, Lightweight ( $545 \mathrm{~kg} / \mathrm{cum}$ at $12 \%$ moisture content) the sap wood and heartwood has no clearly differentiated. The wood has straight grain with fine to medium texture and low lusture. The wood of $A$. cadamba is moderately strong and can be treated with preservatives easily, the treated timber becomes 
durable, and however, the sowing, peeling and other workable operation in this wood are very easy. The A. cadamba wood used in the variety of services such as ceiling boards, light construction work, ply-wood, pencil making, match splints, flooring, pulp wood for paper, packing cases, toys, wooden shoes, tea-chests, carving and crates etc. A. cadamba wood is also used for inexpensive furniture if properly seasoned and treated. The tree is also suitable for aesthetic and ornamental purpose and planted along roadsides. The fruits, leaves and barks of $A$. cadamba got medicinal properties whereas seeds have anti-poison medical properties. The root bark is also used for natural yellow dye. The A. cadamba tree has heavy leaf shedding properties which increases the organic carbon in the soil. The fruits and inflorescences of $A$. cadamba reportedly edible and the fresh leaves are fed to cattle. The scented orange flowers attract Honey- bees as pollinators, moreover the $A$. cadamba flowers are an important raw material used in the Indian perfumes with sandalwood as base and a good bee forage in apiculture.

A. cadamba is light demander in nature but the young plant need protection from sun. It grows generally with a maximum temperature $37.5^{\circ}$ to $47.5^{\circ} \mathrm{C}$ and minimum $0^{0}$ to $15^{\circ} \mathrm{C}$. The seedlings are frost sensitive and liable to damp off during excess moisture in the soil. The species can grow in the mean annual rainfall of 1500 to $5000 \mathrm{~mm}$ [1] however; sometimes the $A$. cadamba can also grow in xeric condition with rainfall of as low as $200 \mathrm{~mm}$. The altitudinal range of growing this species varies from 300 to $1000 \mathrm{~m}$ [5] however; sometimes it can go up to $1400 \mathrm{~m}$. Kadamb prefers deep, moist well drained loamy soil of alluvial origin. It also comes up in the sandy soils of Brahmaputra valley. The species is considered suitable for soil conservation, agroforestry, jhum land reclamation etc. Due to its heavy leaf shedding nature, Organic Carbon content of the soil can be increased.

Young plants of A. cadamba are very susceptible to browsing by the animals. The species has good coppicing ability to be multiplied by vegetative methods. The natural regeneration in $A$. cadamba has observed in favourable condition (light, moisture and well drained soil). Its seeds are very minute has good germination but seeds \& seed sprouts swashed into heap along with silt and rain, hence natural regeneration is difficult. Due to small seed size and sensitiveness of seedling the artificial regeneration is considered to be good in A. cadamba, though the seedling with ball of earth round the root system is considered good.

The mature fruits are orange brown in colour generally available in August to September which are collected from ground and heaped under shade. The most suitable time of collection of seed is middle to later part of August. The mass of the fruits can be allowed for rotting for three to four day and then pulp of the fruits is washed off and the seeds are dried. The fruits are then rubbed to form paste-like slurry and passed through a $0.50 \mathrm{~mm}$ sieve with proper shaking. The average dry weight of a fruit is $11.5 \mathrm{gm}$ and wet weight $50 \mathrm{gm}$ whereas the a $A$. cadamba fruits yields $456 \mathrm{mg}$ of pure seeds (Luna, 1996). The A. cadamba (Kadamb) seeds are minute, trigonal or irregular shaped and measured about 9, 00,000 to
27, 00, 000 seeds/kg (Figure 5 to 8 ).

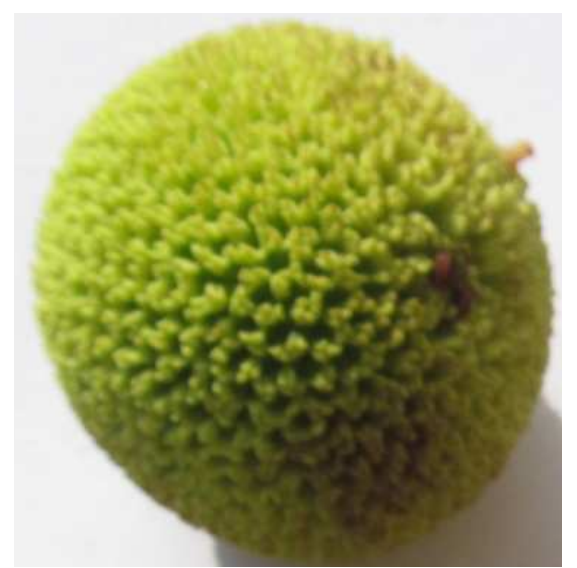

Fig. 5. Fruit of A. cadamba

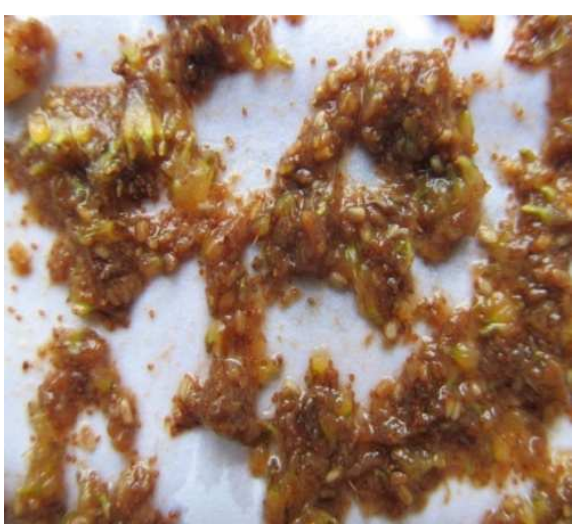

Fig. 6. Rubbed fruits of A. cadamba

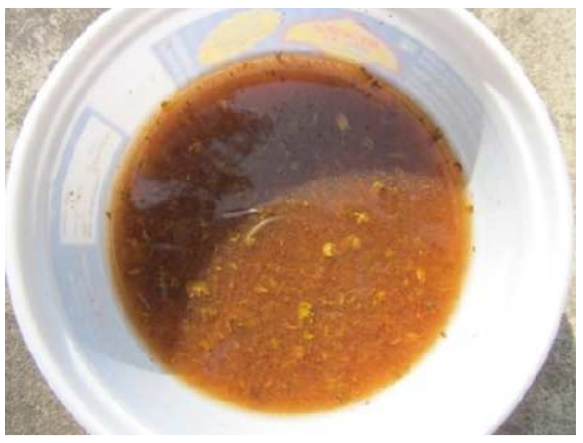

Fig. 7. Slurry of A. cadamba

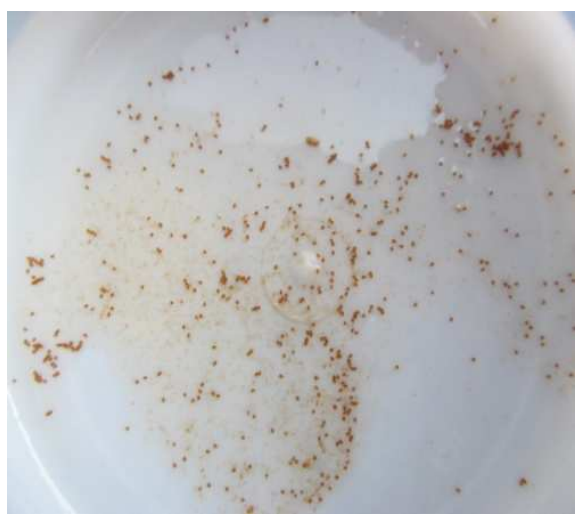

Fig. 8. Seeds of A. cadamba 


\section{Nursery Technique}

Tha A. cadamba seeds do not require any pre-sowing treatment, but need special care during watering, due to minute nature of seeds. The seeds are generally broadcasted on the raised beds@ $130 \mathrm{gm} / \mathrm{m}$ sq and watered properly. About $70 \%$ of germination is observed within 15 days and pricked out into polythene bags where they are retained till the monsoon season arrived. Some time the treatment of 5000 PPM of Indole Butyric Acid (IBA) during rooting and survival in air layering considered valuable, the coppicing is also a method used for regeneration in A. cadamba. Seeds can be sown in galvanized or wooden trays filled with sand and soil and treated with fungicide. The seed sowing on tissue paper for later transplanting of Kadamb seed was also recommended by [6].

\section{Planting Technique}

It has observed that $A$. cadamba is best raised by planting out entire seedlings or polythene bag raised seedlings during June-July at the start of monsoon when they are about 45months old [1]. The natural seedlings collected from the forest (wilding) in August-September when about 30-40 cm height with balls of earth also gives 90 to $100 \%$ success. In Assam, the species has been planted in forest areas which were rendered too open to stock after complete removal of middle canopy layers in the parts [1]. Spacing trials indicate that closer spacing of $1.83 \mathrm{~m} \times 1.83 \mathrm{~m}$ gives the heights yield and the widest spacing of $3.66 \mathrm{~m} \mathrm{X} 3.66 \mathrm{~m}$ the lowest; moreover the spacing appears to have direct effect on the survival of plants [1]. The survival percentage observed to be highest for wider spacing and vice-versa [7]. One more study recommend that $8.5 \mathrm{~m} \times 8.5 \mathrm{~m}$ spacing gives the heights out turn of biomass than either of the wider and closure spacing [8]. In Arunanchal Pradesh, the spacing adopted is $4.5 \mathrm{~m} \mathrm{X}$ $4.5 \mathrm{~m}$ or $5.0 \mathrm{~m} \mathrm{X} 5.0 \mathrm{~m}$ and in West Bengal it is generally $2.0 \mathrm{~m}$ $X 2.0 \mathrm{~m}$ [1]. The closer spacing requires little tending and is liable to push through weeds provided protection against grazing animals is assured.

\section{Rate of Growth}

The species is very fast growing especially in the initial years. As per Troup [9], the A. cadamba trees planted in an avenue at Rajabhathkhowa in Buxa Duars, West Bengal, India reached a girth of $61 \mathrm{~cm}$ and a height of $9 \mathrm{~m}$ in four years. In Assam, it is noticed to attain a tree height of $6.5 \mathrm{~m}$ and tree diameter $12.7 \mathrm{~cm}$ at the age of 4 years [10]. Rate of growth is very fast in the earlier years, the height increment averages $3 \mathrm{~m}$ per annum for the first six or eight years after which the growth becomes slower up to the age of 20 years and thereafter very slow [1]. The optimal rotation of $A$. cadamba plantations can be worked as 10 to 15 years. The Mean Annual Increment (MAI) of 19 years old Kadamb plantation was recorded to be $6.25 \mathrm{~m}^{3} /$ ha in Cooch Bihar [11] however in favourable conditions the trees can attain a diameter of as high as $50 \mathrm{~cm}$ in about $12-15$ years which is good for productivity and Carbon Sequestration.

\section{Pests and Diseases}

The young plants and coppice shoots are readily browsed by cattle, goats and deer. Porcupines chew the bark as also the bioson and Sambher bark the trees [1]. Among the insects, Aristobia approximator feeds on the bark, Dihamnus cervinus bores in the stem, and Dirades adjutaria defoliates over extensive areas [2].

\section{Role in Agroforestry and Carbon Sequestration}

A. cadamba is promising plantation trees for humid and sub-humid tropics. The block plantations of species are mainly grown for industrial uses besides selected areas as agroforestry tree. Pruning in A. cadamba plantations is unnecessary as the species shows natural pruning with dead branches falling off. The rotation period (harvesting time) depends upon the production purpose. For pulpwood and matches, harvesting can start 4-5 years after planting. For example, a match factory in North Sumatra is growing $A$. cadamba on a 4-year rotation under optimal management, which includes fertilisation. For wood production, felling of trees can start approximately from the age of 10 years. In the Philippines, economic rotations applied in plantations are 5 years for pulpwood and 7 years for the combination of pulpwood and sawn timber [12]. It was estimated [13] that the total carbon sequestered in farm forestry with species such as Eucalyptus sp., Populus deltoides, Tectona grandis, Anthocephalus chinensis trees to be around 16,400 t/yr. It was reported [14] that application extracts of leaves and twigs of A. cadamba did not inhibit the growth of turmeric plants and showed no allelopathic effect. This research conducted in the 3.9-year old A. cadamba stands having average shade level of $73.7 \%$. Production of turmeric at the age of 6 months after planting ranged between 7.4 and 11.9 tons per ha and 9.9-16.4 tons per ha at the age of 8 months.

Due to heavy leaf shading during autumn- spring and easy decomposition of leaves make it suitable alternate for wheatpaddy system in most of the parts of India. There is already high demand for species for pencil industry, plywood and match splints and A. cadamba can be extensively adopted in farm forestry in humid tropics for industrial and income generation. Most of the agroforestry in humid tropics concentrated by Casurina equaetifolia, Acacia mangium and Tectona grandis. Recently Melia dubia and Khaya senagalensis are promoted in agroforestry where Anthocephalus kadamba has more potential in terms of growth, yield and economics. A. cadamba sporadically also used as shade tree in tea and coffee plantations. They are resistant for insect pest even in humid tropic conditions.

A. cadamba has minimum shade effect and no alleopathic effect on the agricultural crop advocates its suitability for the 
for agroforestry purpose. The wider adaptability of the tree from semi arid to humid tropics and foothills of Himalayas also make it preferable option for adoptions in most of agroecological zones of India. Being indigenous fast growing early succession tree it can be promoted in new areas or fresh flood plains of most of the river bank cultivation and Tarai areas. Even in marshy areas or puddle crops like paddy, acorus, mint etc. it is best tree combination where most of the tree species affected by pink disease or root rot. It can be suitable in Chattisgarh, West Bengal, Tamilandu, Bihar, Orissa in India where paddy or medicinal crop of acorus is cultivated either sole or in combination on large areas and repetitively. There is need to further selection of better CPTs of A. cadamba for wider adaptability and fast growth to compete with other exotic trees. Though it is better than Gmelina arborea in terms of compatibility with crops and resistance to disease and pest mainly in humid area but growth of Gmelina is fast. A good plus tree selection in natural forests and in private plantations is being done by Institute of Forest Genetics and Tree Breeding (IFGTB), Coimbatore, still the availability of superior plants of ' $A$. cadamba' to the tree growers of India is limited. In the present context where there is scope of Tree Outside Forest (TOF) such fast growing tree species are important for the climate change era for the sequestration of carbon.

There is need to extend the A. cadamba tree adoption in farms through extension and build the linkages for industrial and other uses of tree for better markets and economic returns from the crop. A. cadamba has potential to yield good returns in agroforestry especially in sub humid and humid tropics (Figure $9 \& 10$ ). Though scattered adoption by farmers for the A. cadamba is there but systematic agroforestry system research is required by monitoring and evaluation of multiplication trials of elite germplasm of species developed by different institutes. Considering the importance of $A$. cadamba, it is being cultivated in various parts of India including various regions of Bihar state like Katihar, Purnia, Madhepura, Araria, Supoal, Saharsa, Muzaffarpur, Samastipur, Vaishali, Khagaria, Chapra, West champaran, East champaran, Begusaria and Darbhanga under agroforestry systems.

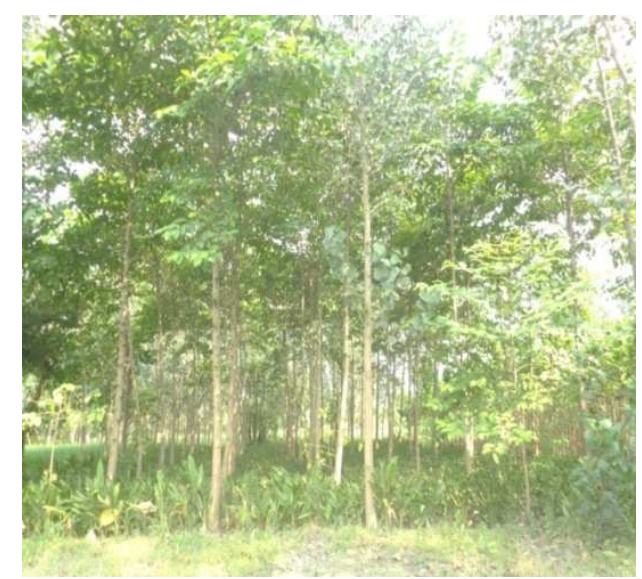

Fig. 9. A. cadamba Plantation in Agroforestry

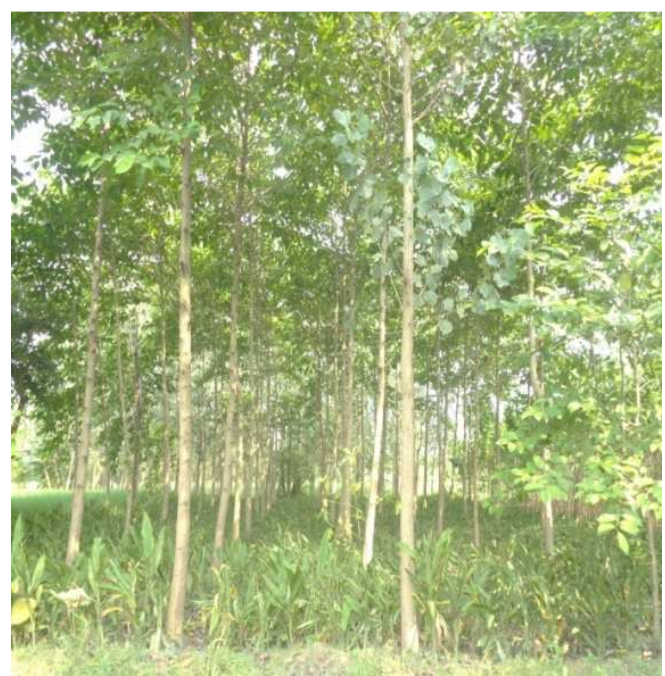

Fig. 10. A. cadamba Plantation in Agroforestry

\section{Economics}

The tree is being cultivated in the gardens and field of the many parts of India. In the West Bengal region this tree is grown in plantation for long times [1], however at present this tree is being used under agroforestry in many parts of the country. As per the estimates done by Institute of Forest Genetics and Tree Breeding (IFGTB), Coimbatore (India), 2012 in Tree Growers fare in an 8 years old A. cadamba tree with a height of $10 \mathrm{~m}$ and a girth of $100 \mathrm{~cm}$ will give $11 \mathrm{Cu} \mathrm{Ft}$ of wood. The average price of one Cubic Fit is about Rs. 250/- comprises to Rs. 2750 per tree. Considering the 400 trees/hectare gives a total of Rs. 11 lakh/hectare at 8 year of age which provides a net benefit of Rs. 9000/month besides additional income from the intercropping as well as ample sufficient amount of Carbon.

\section{Acknowledgement}

The authors are grateful to the Director, IIFM, Bhopal, India; Vice Chancellor and Principle, College of Horticulture and Forestry, Navsari Agricultural University, India and the anonymous reviewers for support and guidance. The special thanks to the Luna, R.K. 1996 for book "Plantation trees of India" and Krisnawati, H., Kallio, M. and Kanninen, M. 2011 Anthocephalus cadamba Miq.: ecology, silviculture and productivity, CIFOR, Bogor, Indonesia for consultation of information about the article. The farmers cultivating $A$. cadamba India are also acknowledged for allowing us to take photographs from their filed.

\section{References}

[1] Luna, R.K. 1996. Plantation trees, IBD Publisher, Dehradun, India.

[2] Annon, 1985. Troup's Silviculture of Indian Trees. Vol VI. Controller of Publications, Delhi. 
[3] Osmaston, F.C. 1927. Nursery and plantation Notes of Bihar and Orissa. Governmanr Printing.

[4] Champion, H. G. and Seth, S. K. 1968. A Revised Survey of Forest Types of India, Govt. of India Press, New Delhi, p. 404.

[5] Martawijaya, A., Kartasujana, I., Mandang, Y.I., Prawira, S.A. and Kadir, K. 1989 Atlas kayu Indonesia Jilid II. Pusat Penelitian dan Pengembangan Hasil Hutan, Bogor, Indonesia.

[6] Venator,C.R et al. 1972. Extraction and germination of Cadamb seed. Research Note. No. ITF14. Institute of Tropical Forestry, Puerto Rico.

[7] Singh, S.P. and Lal, P. 1982. Effect of different spacing treatments on yield from Anthocephalus chinensis plantations. Indian Forester, 108 (12): 734-740.

[8] Rai, S.N. and Sarma, C.R. 1991. Effect of planting spacement on diameter growth of Anthocephalus chinensis. Indian Forester, 117 (12): 1029-1031.

[9] Troup, R.S. 1921. Silviculture of Indian trees. Clarendon Press, Oxford.
[10] Ghosh, R.C. 1977. Handbook of Afforestation Techniques. Controller of Publication, Delhi.

[11] Guhathakurtha, P. and Banerjee, A.K. 1970. The rate of growth of some species in North Bengal. West Bengal Forest Department.

[12] Soerianegara, I. and Lemmens, R.H.M.J. 1993 Plant resources of South-east Asia 5 (1): Timber trees: Major commercial timbers. Pudoc Scientific Publishers, Wageningen, Netherlands.

[13] Singh TP (2003) Potential of Farm Forestry in Carbon Sequestration. Indian Forester 129: 839-843.

[14] Lubis, Muhammad Ripqi 2014. Turmeric (Curcuma Domestica Val.) Plants Under Agroforestry Stands Jabon (Anthocephalus Cadamba Miq.), M.Sc. Thesis- IBP Bogor Agricultural University, http://repository.ipb.ac.id/handle/123456789/68365. 